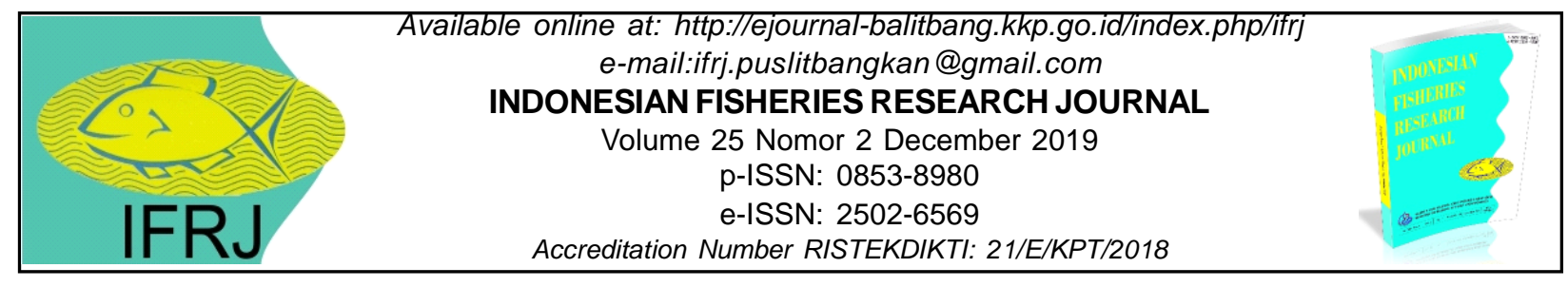

\title{
DIAGNOSTIC AND DESCRIPTION OF ASIAN PANGASIID CATFISH GENUS Helicophagus FROM SOUTHEAST ASIA
}

\author{
Rudhy Gustiano*1, M. H. Fariduddin Ath-thar'1, Vitas Atmadi Prakoso', Deni Radona ${ }^{1}$ and Irin Iriana Kusmini' \\ Institute for Freshwater Aquaculture Research and Fisheries Extension (BRPBATPP), JI. Sempur No 1, Bogor, West Java, \\ Indonesia 16129 \\ Received; April 18-2019 Received in revised from September 27-2019; Accepted October 12-2019
}

\begin{abstract}
Pangasiid catfishes is an economic important catfish family for fishery. Nowadays, three species, Pangasius hypophtahlmus, P. boucorti, and P. djambal, are used in aquaculture. Among the genera in Pangasiidae, Helicophagus was less studied. Although this genus was less preferred than other popular species in Pangasiidae, it still has high commercial price. The present study was conducted to clarify the differences of the exist species in the genus Helicophagus based on biometric analyses. Twenty six specimens, collected from represent rivers in Southeast Asia, used for the material examined. Several type specimens deposited in museums were also added in the analyses. Thirty five characters were designed for measurement on the unique body conformation. Principal component analysis (PCA) was applied to distinguish different species and found strong characters for key identification and description. The results presented the data and information on the diagnosis, description, distribution, and ecology of each species. Key identification of each species are given. The three species (Helicophagus typus, $H$. waandersii, and $H$. leptorhynchus) enabled to show their differences based on eye diameter and vomerine toothplate length.
\end{abstract}

Keywords: Catfish; Pangasiidae; Helicophagus; biometric analysis

\section{INTRODUCTION}

Pangasiids is an economic important catfish family. Nowadays, three species, Pangasius hypophtahlmus, $P$. boucorti, and P. djambal are widely used in aquaculture in Southeast Asian countries. After Gustiano \& Pouyaud (2007; 2008), four genera catfishes consist of Helicophagus, Pangasionodon, Pteropangasius and Pangasius are recognized in the family Pangasiidae. Among them, the genus Helicophagus was less studied compared to other genera. Helicophagus was erected by Bleeker (1858b). Since then, only one paper reported the genus Helicophagus (Musikasinthorn et al., 1998). In the past, only two species were reported in this genus, H. typus Bleeker, 1858 \& H. waandersii Bleeker, 1858. The occurrence of the third species, $H$. leptorhynchus was added by $\mathrm{Ng} \&$ Kottelat (2000) after the genetic study done by Pouyaud et al. (1998).

Helicophagus was often caught together with Pangasius species. Local people in Indonesia call them as "Patin muncung" (Schuster \& Djajadiredja, 1952) meaning patin with extremely protruding snout. In spite of this genus less preferred than other popular patin species due the meat taste, it still has a high price compared to common freshwater consumption species. Therefore, it is important to understand each species properties for fisheries. The present study was conducted to compare the differences of three exist species in the genus Helicophagus based on biometric analyses. Data and information on the diagnosis, description, distribution, and ecology of each species were also included.

\section{MATERIALS AND METHODS}

Twenty six specimens from Musi and Batang River in Sumatra (Indonesia), Kapuas River in Kalimantan (Indonesia), and Mekong River (Laos, Cambodia, and Thailand) deposited in MNHN, MZB, and ZRC were used for the material examined in the study. Three holotype of $H$. typus and $H$. waandersii deposited in British Museum Natural History (BMNH), London and $H$. leptorhyncus deposited in National Museum of Natural History (USNM), New York were also added in the analyses. Thirty five characters (additional for $3 a$ and $3 b$ ) were designed for measurement on the unique body conformation (Fig. 1) and species characterization followed Gustiano et al. (2018). Five 
meristic characters were also counted. Principal component analysis (PCA) was applied to distinguish different species and found strong characters for key identification and description.

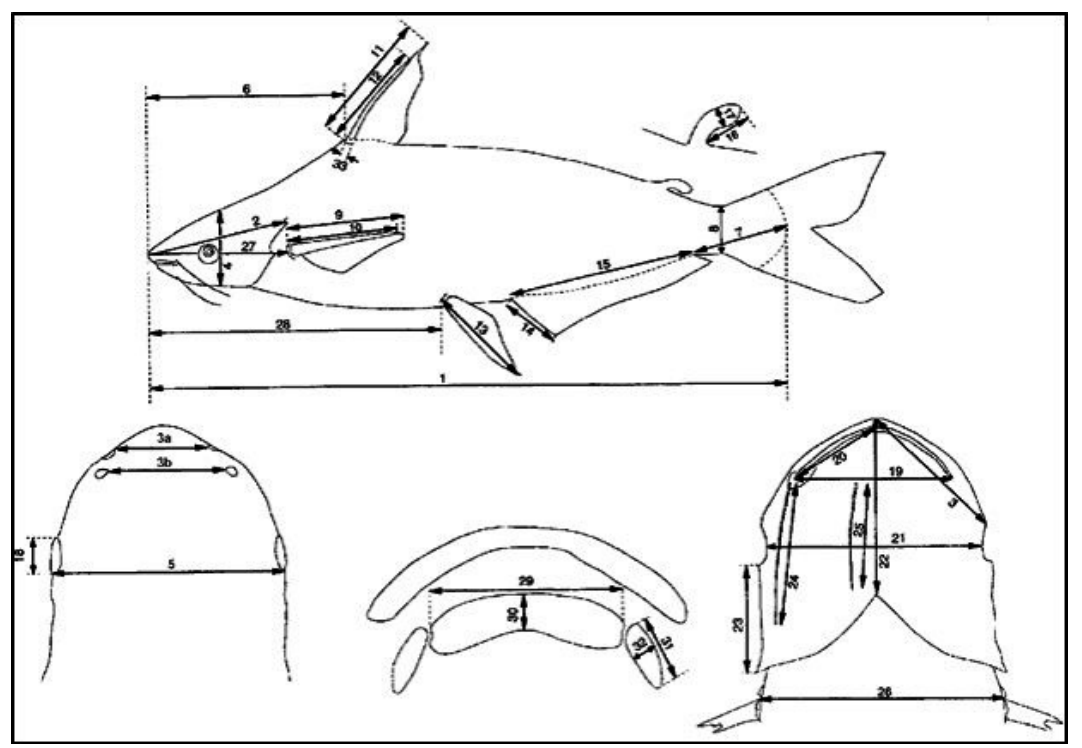

Figure 1. Measurements taken on Pangasius specimens: 1. Standard length; 2. Head length; 3 . Snout length; 3a. Anterior snout width; 3b. Posterior snout width; 4. Head depth; 5 . Head width; 6. Predorsal length; 7. Caudal peduncle length; 8. Caudal peduncle depth; 9 . Pectoral fin length; 10. Pectoral spine length; 11. Dorsal fin length; 12. Dorsal spine width; 13. Pelvic fin length; 14. Anal fin height; 15. Anal fin length; 16. Adipose fin height; 17. Adipose fin width; 18. Eye diameter; 19. Mouth width; 20. Lower jaw length; 21. Interorbital length; 22. Distance snout to isthmush; 23. Postocular length; 24. Maxillary barbel length; 25. Mandibulary barbel length; 26 . Body width; 27. Prepectoral length; 28. Prepelvic length; 29. Vomerine width; 30. Vomerine width; 31. Palatine length; 32. Palatine width; 33. Dorsal spine width.

\section{RESULTS AND DISCUSSION Results}

Based on the analysis of 35 measured and five counted characters, the diagnosis of the family, genus, and the description of the valid species are given below.

Helicophagus has a short and a large premaxillary toothplate; the vomerine toothplate without additional toothplate; the front border of the snout is pierced by anterior nostrils; the posterior nostrils are between and in line with the anterior nostrils and the middle of eye; a narrow mouth $(<35 \% \mathrm{HL})$; a slender anterior part of snout length $(<16.5 \% \mathrm{HL})$ (Gustiano \& Pouyaud, 2008).

The valid species in this genus was examined using PCA analysis of 27 metric characters on 29 Helicophagus specimens. A plot of PCII and PCIII of metric characters is able to distinguish three different groups (Fig. 2); the first group, including the type of Helicophagus typus, is on the positive sector of PCIII; the second group is in the negative sector of PCII containing the specimens of $H$. waandersii; and the third group containing the type of $H$. leptorhynchus that is mostly in the positive sector of PCII. The dominant characters for PCII are vomerine length (0.723471), mandibular barbel length $\quad(-0.509796)$, and eye diameter for PCIII $\quad(-0.434571)$.

Further analysis showed that the plot of PCIII from a PCA of 27 metric characters measured on 29 specimens against PCMI from a PCA of five meristic counts (taken on 29 specimens) isolates a group together with type of $H$. typus in the positive sector of PCMI (Fig. 3). The factor score of the metric counts showed that the dominant characters are anal fin rays and gills raker numbers on the first branchial arch (Table 1).

When the dominant factors from the PCA analysis (vomerine toothplate and eye diameter) are plotted, the figure illustrates three different groups in Helicophagus (Fig. 4). The first group, including the type of $H$. typus, has a small eye diameter $(<14 \%$ $\mathrm{HL}$ ); the second group, containing the type of $H$. waandersii, has a short vomerine toothplate length $(<5 \% \mathrm{HL})$ and eye diameter between $14-24 \% \mathrm{HL}$; the third group, including the type of $H$. leptorhynchus, is recognized by a large vomerine toothplate $(>5 \% \mathrm{HL})$ and eye diameter more than $15.3-27.8 \%$ HL (Fig. 4). 


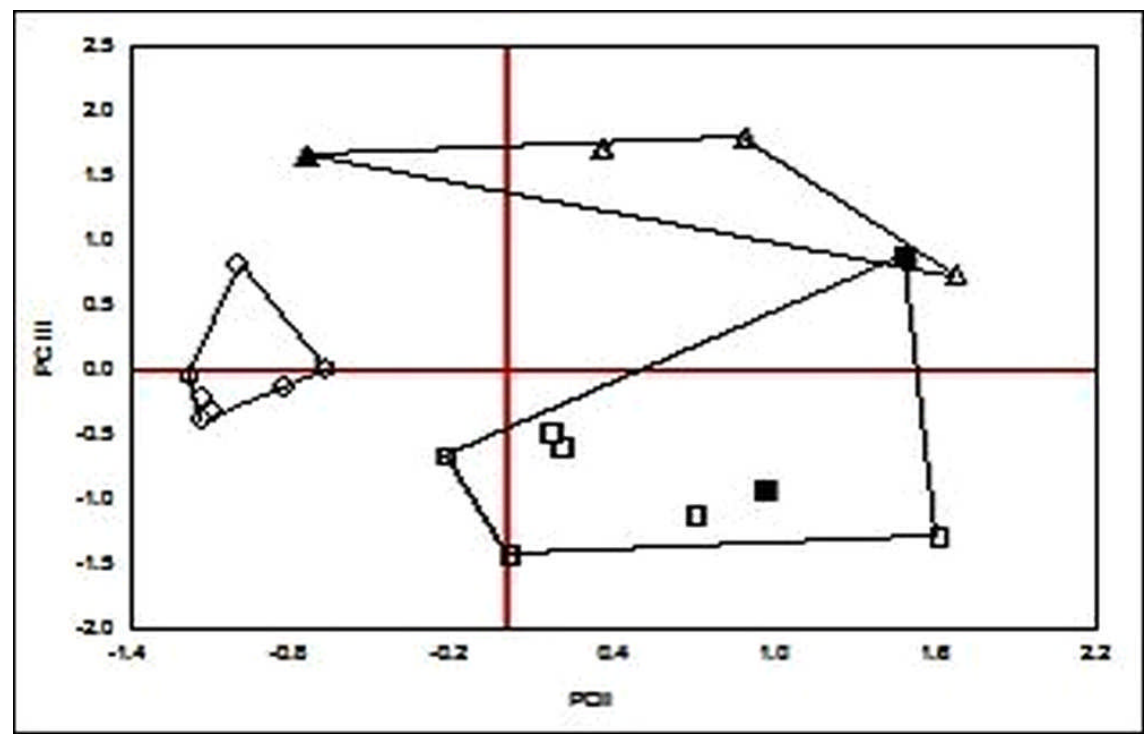

Figure 2. Plot of PCII versus PCIII taken from a PCA of 27 log-transformed variables on 29 specimens. type of Helicophagus typus; $\Delta H$. typus specimens; $\circ H$. waandersii specimens; - type of $H$. leptorhynchus; $\square$ specimens of $H$. leptorhynchus.

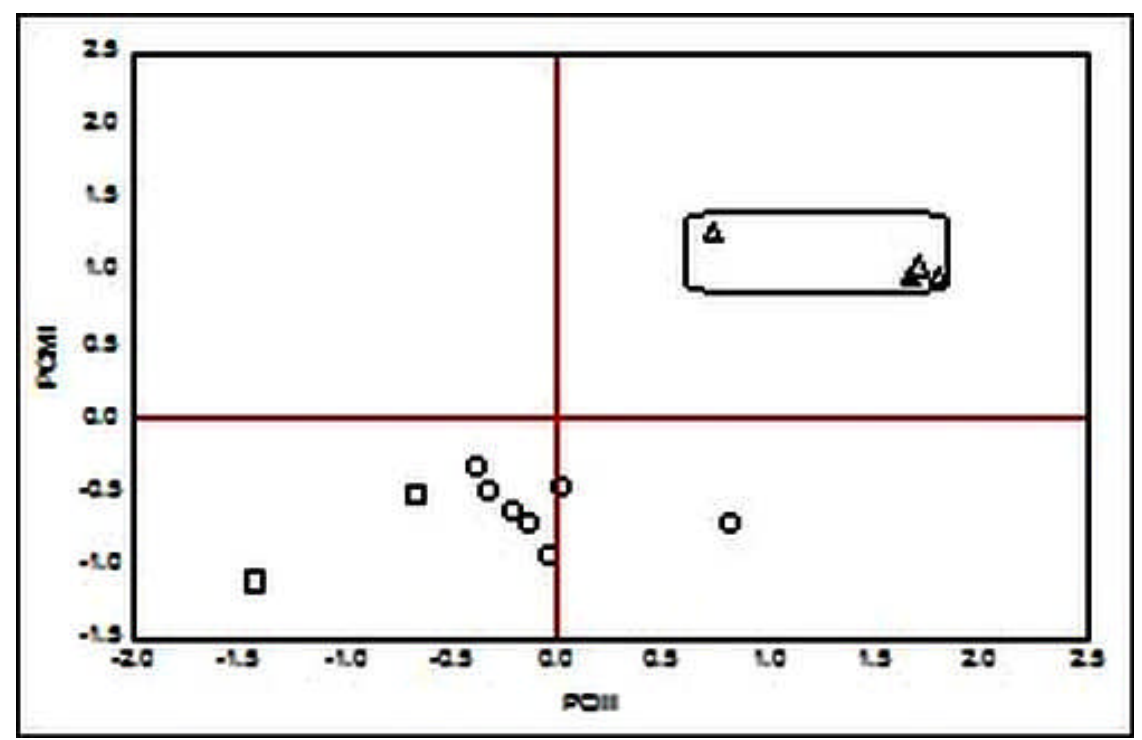

Figure 3. Plot of PCIII derived from a PCA of 27 log-transformed metric characters taken on 29 specimens against PCMI from a PCA of five meristic counts on 29 specimens. $\mathbf{\Delta}$ type of Helicophagus typus; $\Delta H$. typus specimens; $\circ H$. waandersii specimens; $\square$ specimens of $H$. leptorhynchus.

Table 1. First factor score coefficient for the meristic PCA using five counts taken on 29 specimens

\begin{tabular}{ll}
\hline Characters & PCMI \\
\hline Gill raker number & 0.931850 \\
Dorsal rays & 0.515344 \\
Pectoral rays & 0.836766 \\
Anal rays & -0.919149
\end{tabular}




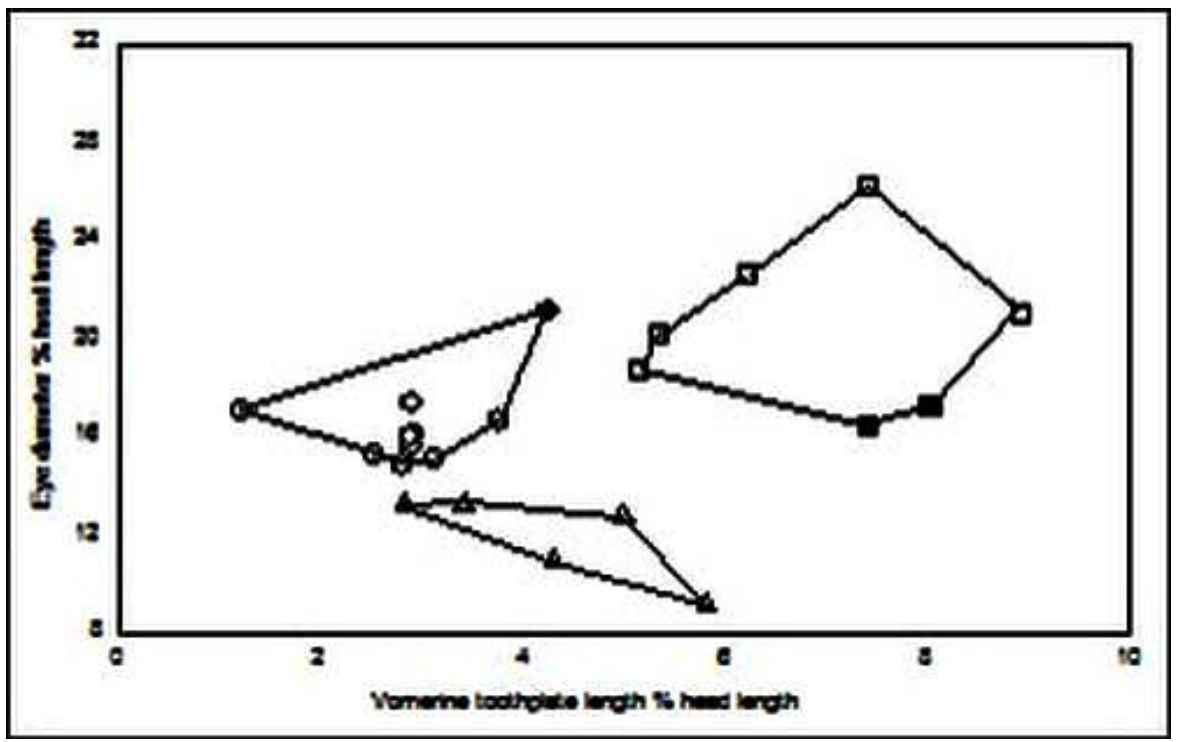

Figure 4. Plot of vomerine toothplate (\% $\mathrm{HL})$ against eye diameter $(\% \mathrm{HL})$. $\Delta$ type of Helicophagus typus; $\Delta$ $H$. typus specimens; - holotype of $H$. waandersii; 。 $H$. waandersii specimens; - type of $H$. leptorhynchus; $\square$ specimens of $H$. leptorhynchus.

\section{Discussion}

Analyses of PCA using metric characters (Fig. 2), combination of metric characters and meristic data (Fig. 3), and combination of strong characters (Fig. 4) enabled to distinguish three different species in the genus Helicophagus. Key of identification and detailed properties of each species are given below.

\section{Key to species}

1a. Anal rays 27-30; premaxillary teeth in a single curved band; gill rakers on the first branchial arch 27-33; eye diameter less than 9.3-13.5\% HL; mandibular barbel less than $35 \%$; anal fin length less than $32.9 \%$;

Helicophagus typus

1 b. Anal ray counts more than 35 ; premaxillary teeth divided into two quadratic bands; gill rakers on the first branchial arch 7-18; eye diameter more than
$14 \% \mathrm{HL}$; mandibular barbel more than $35 \%$; anal fin length more than $33.6 \%$

2a. Vomerine toothplate length $1.2-4.2 \% \mathrm{HL}$; vomerine toothplate length is about one third of premaxillary tooth plate length

H. waandersii

$2 \mathrm{~b}$ Vomerine toothplate length $5.1-8.9 \% \mathrm{HL}$; vomerine toothplate length is about one half premaxillary toothplate.

H. leptorhynchus

\section{Helicophagus typus Bleeker, 1858}

(Fig. 5)

Helicophagus typus Bleeker, 1858b: 45 (type locality Musi River, Palembang, South Sumatra, Indonesia); Günther, 1864: 64; Weber \& De Beaufort, 1913: 252; Hardenberg, 1948: 412; Burgess, 1989: 105; Roberts \& Vidthayanon, 1991: 139; Kottelat, 1993: 100; Musikasinthorn, 1998: 197; Tan \& Ng, 2000: 287.

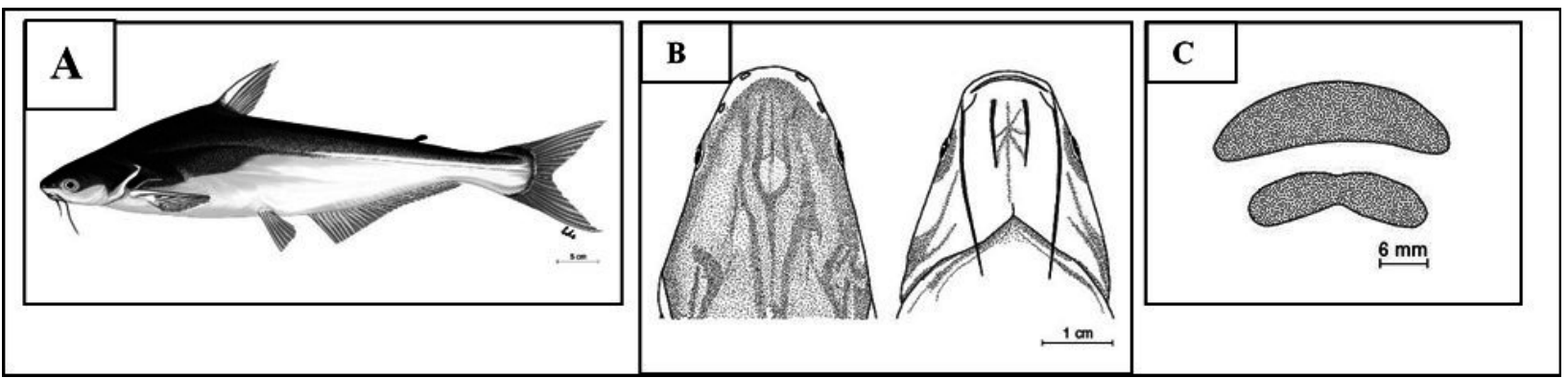

Figure 5. Helicophagus typus. A. Lateral view of specimen (IRD-627, $596 \mathrm{~mm} \mathrm{SL).} \mathrm{B.} \mathrm{Dorsal} \mathrm{(left)} \mathrm{and} \mathrm{ventral}$ (right) view of the head. C. Premaxillary (above) and vomerine (below) toothplates of the same specimen. 
Diagnosis: anal rays 27-30; premaxillary teeth in a single curved band; gill rakers on the first branchial arch 27-33; mandibular barbel less than $35 \% \mathrm{HL}$; eye diameter $9.3-13.5 \% \mathrm{HL}$; anterior part of snout width $14.7-16.5 \% \mathrm{HL}$; anal fin length $29-32.9 \% \mathrm{SL}$; body width $14.4-17.2 \%$ SL; prepelvic length $41.6-48.3 \%$ SL.

Description: based on the holotype and six specimens. Head short, narrow, and conical. Mouth subterminal; vomerine short. Anterior nostrils pierced through front of mouth. Premaxillary and vomerine teeth conical. Maxillary barbels long but never reaching posterior border of operculum; mandibular barbels up to or beyond eye, but never reaching isthmus. Eye small. Postocular distance long. Gill rakers on the first branchial arch 27-33. Fusion vomerine toothplate found in all observed specimens sized from 180 to $628 \mathrm{~mm} \mathrm{SL}$.

Body narrow and elongated; predorsal distance long; anal fin base high and long; abdomen short with short prepectoral and prepelvic distance. Minute adipose fin. Swimbladder with four chambers; first chamber oval, occupies two-thirds of abdomen; second confined to the rest of cavity; third very short; fourth elongated, slender and pointed at tip, extending from the fifth anal ray up to first half of anal fin base length. Maximum observed size $628 \mathrm{~mm} \mathrm{SL}$.

Colour: on live specimens, body pale brownish and darker on dorsum.

Distribution: Helicophagus typus occurs in the major Indonesian drainages: Musi River, Palembang, South Sumatra; Batang Hari River, Jambi, Sumatra;
Kapuas River, Sintang, West Kalimantan; Barito River, Muara Teweh, Central Kalimantan. This species occurs in the middle to upper part of the river basins.

Ecology: this species is molluscivorous. The holotype had the stomach entirely filled with hundreds of small gastropods (Bleeker, 1858b). The stomach of the specimen from West Kalimantan was entirely filled with small clams identified as the bivalve Potamocorbula sp (Musikasinthorn et al., 1998). The gut contents of four specimens obtained from Sumatra were examined and gastropods as well as bivalves were found in the gut ( $\operatorname{Tan} \& \mathrm{Ng}, 2000$ ). In the present study, one specimen from the Musi River had only tubificid worms in the stomach.

\section{Material examined:}

BMNH 1883.12.4.118, holotype, $180 \mathrm{~mm} \mathrm{SL}$, Musi river, Palembang, Sumatra, Indonesia, coll. Bleeker.

MNHN (IRD 1997-627), 1 ex., 596 mm SL, Kapuas River, Sanggau, West Kalimantan, Indonesia, coll. A. Pariselle \& A.H. Kristanto, July 1997.

Five specimens of MZB collection.

\section{Helicophagus waandersii Bleeker, 1858} (Fig. 6)

Helicophagus waandersii Bleeker, 1858a: 175 (type locality Musi River, Palembang, Sumatra, Indonesia); Günther, 1864: 65; Weber De Beaufort, 1913: 253, Fig. 102. Kottelat et al., 1993: 100; Tan \& Ng, 2000: 287.

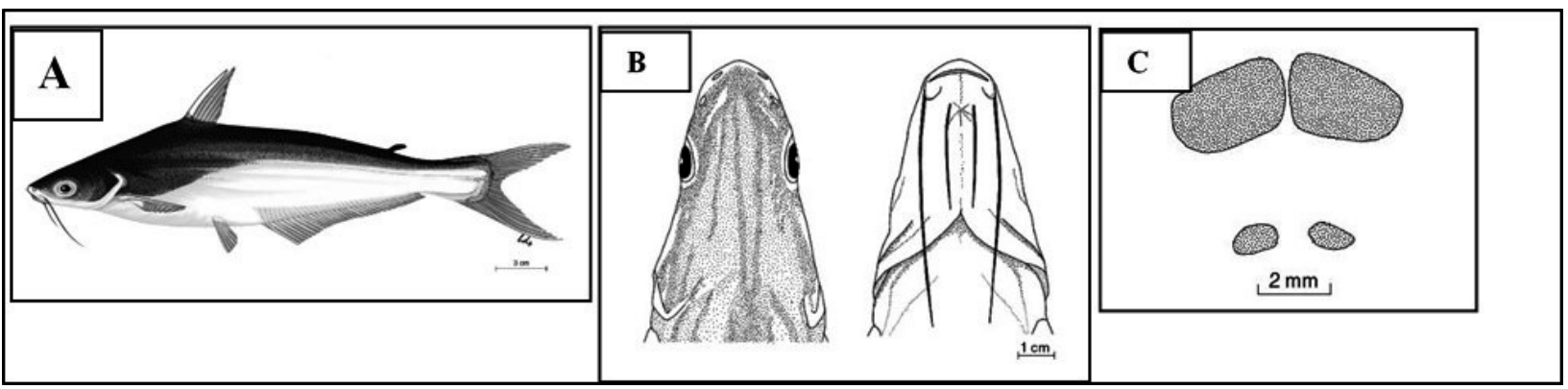

Figure 6. Helicophagus waandersii. A. Lateral view of specimen (IRD-166, $242 \mathrm{SL}$ ). B. Dorsal (left) and ventral (right) view of the head. C. Premaxillary (above) and vomerine (below) toothplates of the same specimen.

Diagnosis: anal rays $36-39$; premaxillary teeth divided into two quadratic bands; gill rakers on the first branchial arch 7-12; eye diameter $14.9-21.2 \%$ $\mathrm{HL}$; vomerine toothplate length 1.2-4.2\% $\mathrm{HL}$; vomerine toothplate length is about one third of premaxillary toothplate length.
Description: based on the holotype and nine specimens. Head small. Mouth subterminal; premaxillary and vomerine teeth conical. Maxillary barbels reaching beyond the border of operculum; mandibular barbels reaching beyond the isthmus. Separation vomerine toothplate found in all observed 
specimens sized from 204 to $281 \mathrm{~mm} \mathrm{SL}$.

Body narrow and elongated; predorsal distance long; prepectoral and prepelvic distance short; anal fin base high and long. Three chambered swimbladder; first oval and short about one third of body cavity; second slender, its length up to just before anterior part of anal fin base origin; third slender and gradually smaller at tip, extending up to two third beyond the beginning of anal fin base. Maximum size observed $281 \mathrm{~mm} \mathrm{SL}$.

Colour: on live specimens, body pale silvery grey on lateral side of head, dorsum, and upper part of flanks.

Distibution: this species occurs in the major river basins in Sumatra, especially Batang Hari River in Jambi Province. Lim \& Ismail (1995) reported that the species also exists in Pahang River, Peninsula Malaysia.

Ecology: this species is molluscivorous, feeds predominantly on bivalves.

\section{Material examined:}

BMNH 1863.12.4.894, holotype, $281 \mathrm{~mm}$ SL, Musi River, Palembang, Sumatra, Indonesia, coll. Bleeker, 1863.

Four specimens of MNHN collection.

Five specimens of MZB collection.

Helicophagus leptorhynchus $\mathrm{Ng}$ \& Kottelat, 2000 (Fig. 7)

Helicophagus leptorhynchus $\mathrm{Ng} \&$ Kottelat, 2000: 55-58. (about $7 \mathrm{~km}$ West of Ubon Ratchathani, Thailand).

Helicophagus waandersii (non Bleeker): Hora, 1937: 256; Durand, 1940: 21; Kottelat, 1985: 269; Kottelat, 1989: 14; Smith, 1945: 371; Roberts \& Vidthayanon, 1991: 139; Vidthayanon, 1993: 15; Rainboth, 1996: 152.

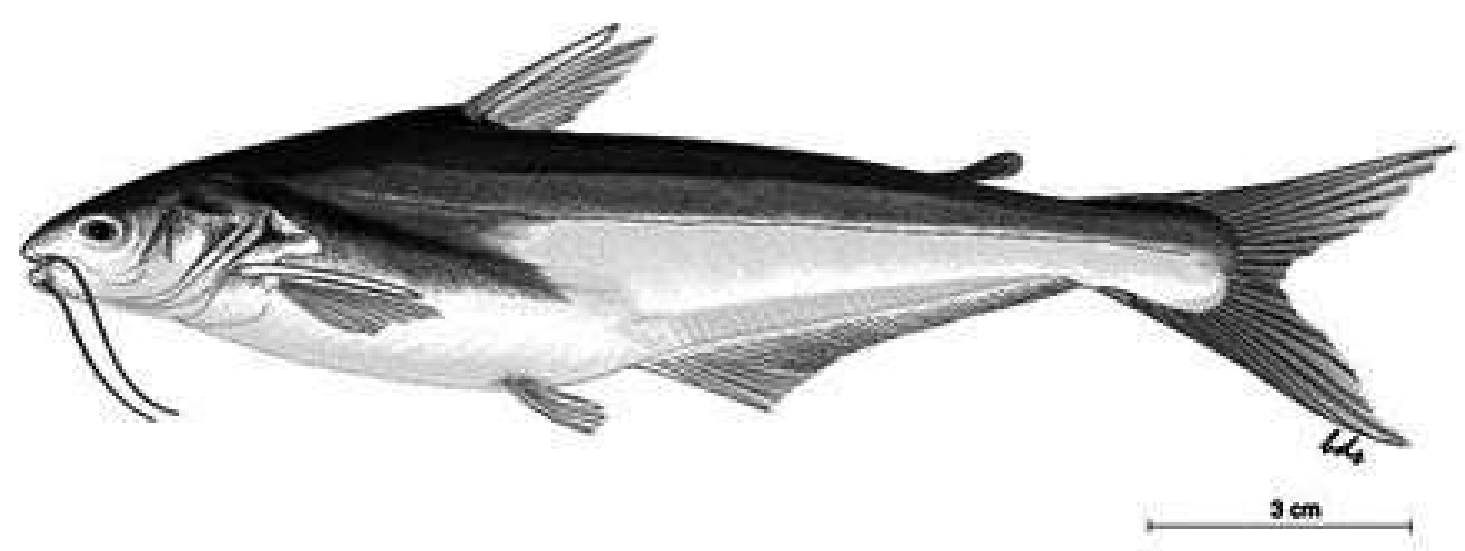

Figure 7. Helicophagus leptorhynchus. Lateral view of holotype (USNM 288676, $131 \mathrm{~mm} \mathrm{SL).}$

Diagnosis: anal fin ray counts 35-41; premaxillary teeth divided into two quadratic bands; gill rakers on the first branchial arch 10-18; eye diameter 15.3-27.8\% $\mathrm{HL}$; vomerine toothplate length 5.1-8.9\% $\mathrm{HL}$; vomerine toothplate length is about one and a half premaxillary toothplate length.

Description: based on the holotype, 2 paratypes and 9 specimens. Head short and slender. Mouth subterminal; premaxillary and vomerine teeth conical. Maxillary barbels nearly or reaching beyond border of operculum; mandibular barbels reaching beyond the isthmus. First branchial arch with 10-18 gill rakers. Body narrow and elongated; predorsal distance long; prepectoral and prepelvic distance short. Anal fin base high and long with 35-41 fin rays. Two chambered swimbladder; first large, oval and short about one third of body cavity; second as long as the first but slender and gradually smaller at tip. Vertebrae $46-48(\mathrm{Ng} \&$ Kottelat, 2000). Maximum observed size 472 mm SL.

Colour: the specimens are grey on the dorsal regions and the upper third of the flanks. A small patch of grey present on the humeral region, immediately above the pectoral fin. Lower two-thirds of the flanks and ventral region whitish. Base of fins dark yellow, distal regions of dorsal and caudal fins black, distal regions of other fins hyaline. In life body silvery to 
grey or pinkish, dorsal, anal, caudal and pelvic fins reddish ( $\mathrm{Ng} \&$ Kottelat, 2000).

Distribution: known from Chao Phraya and Mekong Basins (Fig. 8) (Ng \& Kottelat, 2000).

Ecology: Helicophagus leptorhynchus is molluscivorous, feeds predominantly on bivalves as found in intestine of holotype. Helicophagus leptorhynchus in the Mekong stays in permanent river channels and does not move into the flooded forest. This species migrates upstream when water levels begin to rise at the beginning of the flood season and moves downstream as the water clears at the end of the flood season (Rainboth, 1996).

\section{Material examined:}

USNM 288676, 130.8 mm SL, holotype, Mun River, Bung Wai (about $7 \mathrm{~km}$ West of Ubon Ratchathani), Thailand, Coll. WBD Mekong expedition, September 1971. ZRC 43590, paratypes, 2 ex, 116 and $276 \mathrm{~mm}$ SL, market at That Phanom, Nakhon Phanom Province, Thailand, Coll. Y.Y. Goh and Y.X. Chai, Juni 1998.

Four specimens of ZRC collections.

Five specimens of MNHN collections.

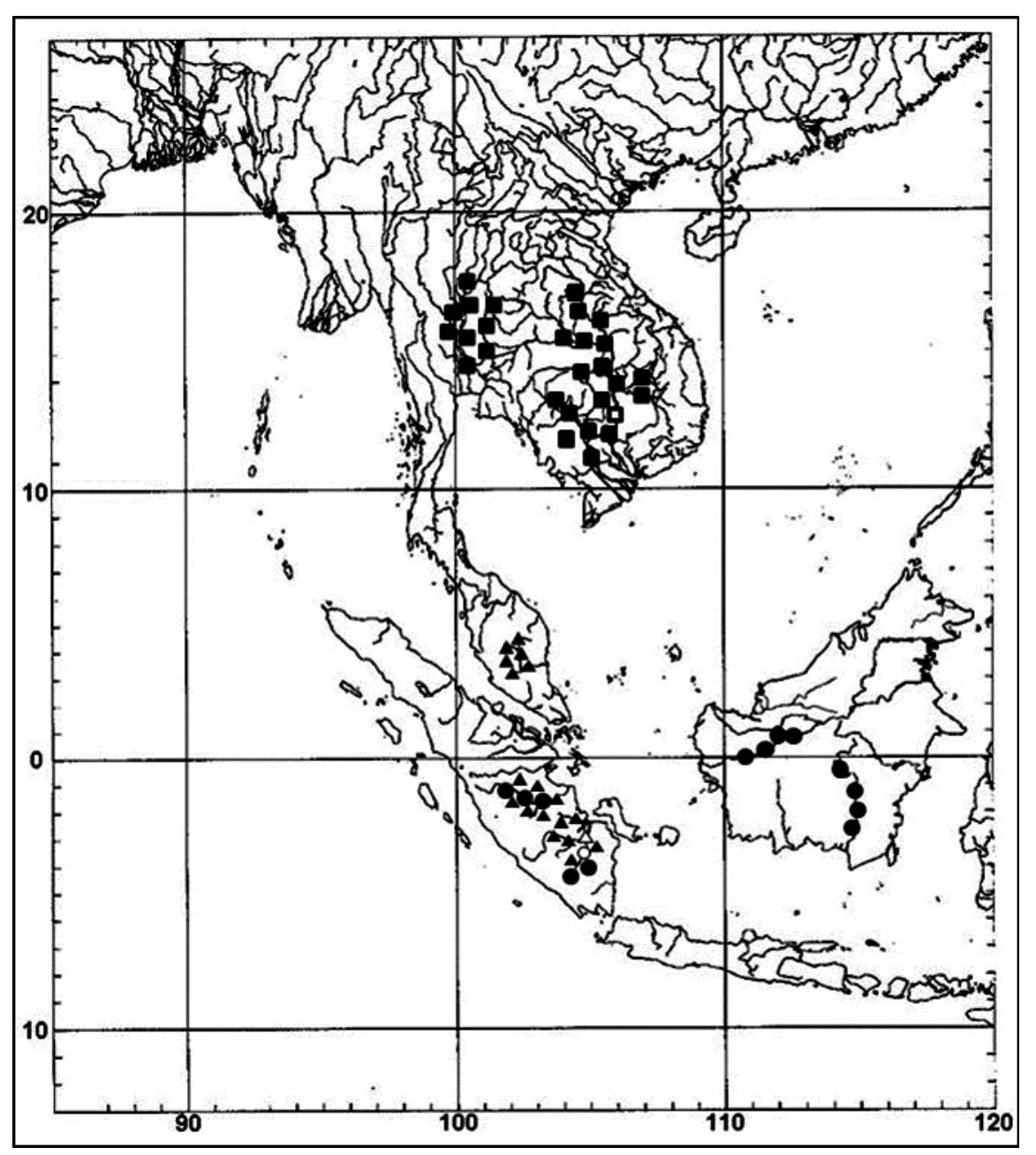

Figure 8. Reconstruction of the geographic distribution of Helicophagus typus, $H$. waandersii, and $H$. leptorhynchus based on present research and references exist. • circle indicates the specimens of Helicophagus typus examined. o circle indicates type locality of $H$. typus. $\Delta$ triangle indicates the specimens of $H$. waandersii examined. $\boldsymbol{\Delta}$ triangle indicates type locality of $H$. waandersii. - square indicates the specimens of $H$. leptorhynchus examined. $\square$ square indicates type locality of H. leptorhynchus 


\section{CONCLUSION}

The three species (Helicophagus typus, $H$. waandersii, and $H$. leptorhynchus) enabled to show their differences based on eye diameter and vomerine toothplate length. Key identification, diagnosis, and description of each species are very useful and practice in field.

\section{ACKNOWLEDGEMENTS}

The authors thank the colleagues in the Catfish Project for collecting fish samples. Special thanks due to G. Teugels (late) and L Pouyaud for his encouragement to the present study. The authors are also grateful to AARD for the fellowship to complete this study through "PAATP" Project at KU LEUVEN, Belgium. The study was a part of "Catfish Asia" project financed by the European Union (contract IC 18-CT 96-0043).

\section{REFERENCES}

Bleeker, P. (1858a). Ichthyologiae arcipelagi indici prodromus. Vol. I. Siluri. Lange \& Co., Batavia, Nederland-Ind. 370p.

Bleeker, P. (1858b). Zesde bijdrage tot de kennis der vischfauna van Sumatra. Visschen van Padang, Troessan, Priaman, Sibogha en Palembang. Act. Soc. Sci. Indo-neerl., 3, 1-50.

Burgess, W. E. (1989). An atlas of freshwater and marine catfishes. A preliminary survey of the Siluriformes. TFH Publication, Neptune City, Canada, 28, 305-325.

Durand, J. (1940). Notes sur quelques poissons d'espèces nouvelles ou peu connues des eaux douces Cambodgiennes. Not. Inst. Océanogr. Indochine, 36, 1-40.

Günther, A. (1864). Catalog of the physostomi containing families Siluridae, Characinidae, Haplochitonidae, Sternoptychidae, Scopelidae in the collection of the British Museum, London. $455 \mathrm{p}$.

Gustiano, R., \& Pouyaud, L. (2007). Taxonomy and genetic relationships of Pangasiidae, Asian catfishes, based on morphological and molecular analyses. Indonesian Aquaculture Journal, 2(2), 107-112. http://dx.doi.org/10.15578/ iaj.2.2.2007.107-112

Gustiano, R., \& Pouyaud, L. (2008). Systematic revision of the genera of Pangasiidae (Siluriformes,
Ostariophysi). Indonesian Aquaculture Journal, 3(1), 13-22. http://dx.doi.org/10.15578/ iaj.3.1.2008.13-22

Gustiano, R., Prakoso, V. A., \& Ath-thar, M. H. F. (2018). Asian catfish Genus Pangasius: Diagnosis and distribution. Indonesian Fisheries Research Journal, 24(2), 99-115. http://dx.doi.org/10.15578/ ifrj.24.2.2018.99-115

Hardenberg, J. D. F. (1948). Some new or rare fishes of the Indo-Australian Archipelago. Treubia, 19, 407-415.

Hora, S. L. (1937). Catfishes of the genus Helicophagus Bleeker. Records of the Indian Museum, 39(3), 235-240.

Kottelat, M. (1985). Fresh-water fishes of Kampuchea. Hydrobiologia, 121, 249-279.

Kottelat, M. (1989). Zoogeography of the fishes from Indochinese inland waters with an annotated checklist. Bull. Zoöl. Mus. Univ. Amsterdam, 12, 1-55.

Kottelat, M., Whitten A.J., Kartikasari S.R., \& Wirjoatmodjo, S. (1993). Freshwater fishes of Western Indonesia and Sulawesi. Periplus edition Ltd, Hongkong. 293 p.

Lim, K. K. P., \& Ismail, M. Z. (1995). The occurrence of the catfish Helicophagus waandersii (Pisces: Pangasiidae) in Peninsular Malaysia. Malay. Nat. 49, 37-40.

Musikasinthorn, P., Utsugi, K., \& Watanabe, K. (1998). Rediscovery of the Pangasiid catfish Helicophagus typus in Borneo. Nat. Bull. Siam. Soc, 46, 197201.

Ng, H. H., \& Kottelat, M. (2000). Helicophagus leptorhynchus, a new species of molluscivorous catfish from Indochina (Teleostei: Pangasiidae). Raffles Bulletin of Zoology, 48(1), 55-58.

Pouyaud, L., Gustiano, R., \& Legendre, M. (1998). Phylogenetic relationships among Pangasiid catfish species (Siluriformes, Pangasiidae) and new insights on their zoogeography. In: Legendre, M. (ed.), \& Pariselle, A. (ed.). The biological diversity and aquaculture of clariid and pangasiid catfishes in South-East Asia : proceedings of the mid-term workshop of the "Catfish Asia project". Jakarta (IDN); Can Tho: IRD; Can Tho University, 49-56. 
Rainboth, W. J. (1996). Fishes of the Cambodian Mekong. FAO species identification field guide for fishery purposes. Rome, FAO. $265 \mathrm{p}$.

Roberts, T. R., \& Vidthayanon, C. (1991). Systematic revision of the Asian catfish family Pangasiidae, with biological observations and descriptions of three new species. Proceedings of the Academy of Natural Sciences of Philadelphia, 97-143.

Schuster, W. H., \& Djajadiredja, R. R. (1952). Local common names of Indonesian fishes. W. van Hoeve for the Ministry of Agriculture of Indonesia, Laboratory for Inland Fisheries.
Smith, H. M. (1945). The freshwater fishes of Siam or Thailand. Bull. U.S. Natl. Mus., 188, 1-622.

Tan, H. H., \& Ng, H. H. (2000). The catfishes (Teleostei: Siluriformes) of central Sumatra. Journal of Natural History, 34(2), 267-303.

Vidthayanon, C. (1993). Taxonomic revision of the catfish family Pangasiidae. Ph.D. Thesis. Tokyo University of Fisheries. 203 p.

Weber, M., \& De Beaufort, L. F. (1913). The fishes of the Indo-Australian. Arch. II. Malacopterygii, Myctophoidea, Ostariophysi: I. Siluroidea. Leiden: E. Brill. 